\title{
UPPER SECONDARY SCHOOL TEACHERS' FIRST ENCOUNTER WITH THE ACTIVE LEARNING CLASSROOM: WHAT CAN WE LEARN FROM A PERSPECTIVE OF POWER AND CONTROL?
}

\author{
Peter Bergström ${ }^{1}$, Maria Rönnlund ${ }^{1}$ and Åse Tieva ${ }^{2}$ \\ ${ }^{1}$ Umeå University, Department of Applied Educational Science, Johan bures väg 14, SE-901 87 Umeå, Sweden \\ ${ }^{2}$ Umeå University, Centre for Educational Development, SE-901 87 Umeå, Sweden
}

\begin{abstract}
This paper reports on a research and development project based upon problems in upper secondary school, namely students' lack of engagement, passive learning and students' absence from school. Looking to solve this problem, a group of upper secondary school teachers came across and saw potential in the concept, physical space and method of the "Active Learning Classroom (ALC)", a concept from higher education. The aim of this particular study was to explore teaching in the ALC from the perspective of power and control. The research questions embrace issues on both the physical learning environment of the ALC, teacher practices in the ALC and what kind of teacher practices enhance active learning. The theoretical framework was based on Bernstein's concepts of power and control. The study applied methods of video recorded classroom observations and field notes. The findings indicate a designed physical learning environment where power was conferred to the students. That placed demands on the teachers with regard to how they handled control in practice. Findings further indicate that when teachers had more active control over pace and sequencing, this increased productivity and more active learning among the students.
\end{abstract}

\section{KEYWORDS}

Active Learning Classroom, Teacher, Pace, Sequence, Power and Control

\section{INTRODUCTION}

Most people have an experience of classroom teaching with a teacher at the front of the classroom talking to silent students sitting in straight lines, facing the teacher, similar to Freire's (1970) banking model. Such teaching has been labelled as traditional teaching or teacher-centred learning (Barr \& Tagg, 1995; Carlgren et al., 2006). In contrast, a student-centred learning (Barr \& Tagg, 1995) approach is reported in terms of so-called active learning, based on student-driven tasks including assignments where students create understanding, meaning, and new ideas. Further, being active in learning means a learning approach that helps students expand their thinking beyond consumption type behaviour and traditional reproduction of existing knowledge where students apply or create new knowledge to solve a problem by using both peers and, not frequently, various information and communication technologies (ICT) (Jahnke et al., 2017).

This study focuses on a school development project initiated by teachers in one Swedish upper secondary school, who witnessed students' lack of engagement, passive learning and students' absence from school. From their daily practice in the school, they saw a need to expand their repertoire of teaching methods from the use of teacher-centred learning methods to teaching methods where students' active learning increased. During, and as part of the development process, the teachers came across and saw potential in a method and model developed in higher education called Active Learning Classroom (ALC) (Baepler et al., 2016). Accordingly, the school decided to create a room designed using principles from the ALC model with regard to furniture and ICT. In the first phase of the project, the teachers designed the room according to some ALC principles of using round tables for groups of students, access to whiteboards, and digital facilities such as smartboards, interactive pens, projectors, and student laptop access. In the second phase, teachers started to teach students in the ALC. 
This paper focuses on the second phase and what happened to teacher practices when they shifted space from the familiar and ordinary classroom space to the new experience of the ALC. The aim is to explore teaching in an active learning classroom from the perspective of power and control at upper secondary school level. The following research questions were addressed: 1) How can the physical space of the ALC be described and understood? 2) How can teacher practices in the ALC be described and understood? 3) What kind of teaching practices enhance active learning in the ALC?

The next section presents literature related to active learning and teacher practices before continuing with the method and the theoretical framework.

\section{LITERATURE}

The key concept in this project is active learning, which has been addressed in policy documents (OECD, 2013) as well as in the work of John Dewey and his progressive pedagogy. The term active learning classroom can be understood as a two-fold principle with regard to both active learning pedagogies and principles about the physical classroom space (Baepler et al, 2014). Regarding active learning pedagogies, previous definitions of active learning touch upon dichotomies between teacher-centred learning and student-centred learning, for example by limiting activities based on transmission of information and instead increasing student discussions and analysis (Bonwell \& Eison, 1991). Recent research positions active learning explicitly as a sub-term to student-centred learning, where active learning is defined as teaching and learning that is individualised and adaptive (Bernard, Borokhovski, Schmid, Waddington and Pickup, 2019).

When considering active learning in relation to physical classroom spaces, an extensive number of studies from the context of higher education report on the active learning classroom (ALC) (Whiteside, et al, 2010; Brooks, 2011; Baepler et al, 2014; Baepler, et al, 2016; Hyun et al, 2017). Active learning in higher education can broadly be understood as a shift in the teacher-student relationship, where students in their role become more of a teacher and take responsibility for knowledge construction. Other characteristics concern the use of the flipped classroom, where lectures are consumed before entering the ALC. Research results convincingly shows increased students' performance in the ALCs compared to traditional classroom settings (Whiteside et al, 2010; Brooks, 2011; Baepler et al, 2014; Lundahl, et al, 2017). Other benefits of ALCs concern improved student attendance and attitudes (Hyun et al, 2017).

Literature on active learning in the context of K12 education has been scrutinised in Bernard et al.'s (2019) systematic review and meta-analysis of 299 studies. Bernard et al. (2019) report on effect size regarding the categories: 1) teacher role, 2) flexibility, 3) pace, and 4) adaptability. Further, these categories were used to show how control was either retained by the teacher (e.g. when lecturing), or distributed to the students (e.g. when the teacher acts as a facilitator who clarifies and encourages). Similar to what has been found in other meta-studies (Hattie, 2008), the most important skill for active learning seems to be in the teacher role with abilities to facilitate students' process by acting as a "guide on the side" rather than a "sage on the stage" (King, 1993). To be a guide on the side can, for example be related to teachers' ability to monitor pace, as Bernard et al. concluded: "pacing of instructional events in a classroom is more productive when it is less student-centred than when it is more student-centred" (Bernard et al, 2019, p. 23). In qualitative studies, findings from one-to-one computing classroom research shown that, among other things, pace was also connected to how teachers sequenced material (Bergström et al, 2019; Bergström, 2019; Bergström \& Mårell-Olsson, 2018). These studies showed that when pace and sequence was less student-centred, teachers' communication and actions were focused on having students busy in activities, at the expense of a lack of insight into the quality of students' learning.

In this particular study, a group of upper secondary school teachers recontextualised the ALC concept developed in higher education and put it into their context of an upper secondary school. The study explores the teachers' experience of teaching in the ALC by focusing on expected power relations arising from the ALC space as such, as well as teachers' control in relation to pace and sequencing of lessons in that space. 


\subsection{Theoretical Framework}

Bernstein (2000) argues that education and educational situations are relays of power relations and regulatory principles. The school teaches knowledge and conveys values of how to behave as a student. To illustrate power and control mechanisms, Bernstein used the concepts of classification and framing. Classification addresses symbolic borders and power relations between categories, for example between school subjects or between objects in a space. Classification categories hold relative power positions, either strong $(\mathrm{C}+)$ or weak (C-) classification or degrees in between, and any attempt to change the degree of separation in the relationship will reveal the power relationship on which the classification was established (Bernstein, 2000). The concept of framing indicates how strong or weak the teacher controls, say, the knowledge content, the knowledge acquisition and the communication in the classroom (Bernstein, 2000). The framing can be strong $(\mathrm{F}+)$ or weak (F-) or degrees in between. For example, strong framing means that the teacher largely regulates and controls what students should work with and at what pace it should take place, while weak framing means that the students have a great influence over this. In previous research, classification and framing have been used in various analyses of educational practices including analyses of physical learning environments and teachers' practices (e.g. Bergström et al 2019, Bergström, 2019). In our analysis of power and control in ALC, we look at how the organisation of, for example, furniture and equipment in the physical space gives signals of power relations between students and teachers (classification) (RQ1). We also look at the extent to which teachers control classroom practice (framing) (RQ2). Thus, we apply Bernstein's theoretical concepts at the micro level of the classroom, with the support of a model that Bergström et al. (2019) and Bergström (2019) have developed and where Bernstein's concepts of classification and framing are operationalised. Regarding the analysis classification - expected power relations arising from the space — four classroom-specific classification categories were used: "desks" (how desks are placed in the room), "inside-outside the classroom" (how the classroom space is restrict to other school spaces), "digital resources" and "material resources" (how these are placed in the classroom space). Each of these categories gives signals of how power is expected to be distributed among students and teachers in the classroom. Table 1 illustrates the classification category "desks" and how, according to Bergström's model, this distributes power between students and teachers based on how the desks are organised in the classroom space.

Table 1. Extract from one of the classification categories

\begin{tabular}{lll}
\hline Theme & Strong classification $(\mathrm{C}+)$ & Weak classification $(\mathrm{C}-)$ \\
\hline Desks & From front to back: desks & From front to back: \\
& in straight lines, corridors & variations in the \\
& From left to right: & organization, for example \\
& separation of students & $\begin{array}{l}\text { desks in groups, no clear } \\
\text { path }\end{array}$ \\
& From left to right: \\
& opportunities for student- \\
& student interaction
\end{tabular}

Regarding the analysis of teachers' control in practice (RQ2) we looked at the framing categories "pace" (to what extent the teacher controlled the pace during lessons) and "sequence" (to what extent the teacher controlled in what order tasks are to be done). Table 2 illustrates, according to Bergström's model, an extract of what guided the analysis in the category "pace" regarding the use of strong and weak control over time. 
Table 2. Example of an extract from the category 'pace'

\begin{tabular}{|c|c|c|c|c|c|}
\hline Category & Indicator & $\mathrm{F}++$ & $\mathrm{F}+$ & F- & F-- \\
\hline Pace & $\begin{array}{l}\text { Teacher-student } \\
\text { communication } \\
\text { in practice }\end{array}$ & $\begin{array}{l}\text { The teacher } \\
\text { monitors strongly } \\
\text { the learning } \\
\text { activities and } \\
\text { change activity } \\
\text { when he/she has } \\
\text { said what is } \\
\text { needed }\end{array}$ & $\begin{array}{l}\text { The teacher has } \\
\text { a clear aim of } \\
\text { what students } \\
\text { shall accomplish } \\
\text { during the } \\
\text { lesson, but the } \\
\text { teacher } \\
\text { monitors the } \\
\text { start/stop of a } \\
\text { new activity in } \\
\text { relation to } \\
\text { students' } \\
\text { progress }\end{array}$ & $\begin{array}{l}\text { The students } \\
\text { monitor the } \\
\text { time they need } \\
\text { for an activity, } \\
\text { but the teachers } \\
\text { press them to } \\
\text { finish work }\end{array}$ & $\begin{array}{l}\text { No time } \\
\text { determined in the } \\
\text { exploring of texts } \\
\text { time depends on } \\
\text { pupils' pace and } \\
\text { there is no } \\
\text { pressure from the } \\
\text { teacher }\end{array}$ \\
\hline \multicolumn{6}{|c|}{ Example of how transcripts have been categorised in relation to strong and weak framing } \\
\hline \multicolumn{6}{|c|}{$\begin{array}{l}\text { F++ "I will give you the instructions one at the time. For the first step you have } 10 \text { minutes, the next step } 20 \\
\text { minutes, and for the last step you have } 30 \text { minutes" }\end{array}$} \\
\hline \multicolumn{6}{|c|}{ F+ Student: we are about 20 minutes behind the others } \\
\hline \multicolumn{3}{|c|}{ Teacher: yes, but you can make it } & \multicolumn{3}{|c|}{ F- "Have you pushed the material to GIT?" } \\
\hline \multicolumn{6}{|c|}{$\begin{array}{l}\text { F-- "I thought we should work until the break, at least, and then we consider how far you reached, and if you are } \\
\text { not finished we will continue after the break" }\end{array}$} \\
\hline
\end{tabular}

\section{RESEARCH METHOD}

This study took place at an upper secondary school with 18 teachers and 200 students. The study was based on a qualitative research design where a group of three teachers collaborated with researchers for three years, starting in the autumn of 2017. During the first year the Active Learning Classroom (ALC) was designed and built. Thereafter the teachers started to use the ALC and the researchers followed them during a period of six months when they started to use the ALC. We observed and filmed the teachers in practice and participated in their planning meetings where they evaluated and planned lessons. During this period, the researchers did not intervene with a predetermined purpose. Instead, the researcher's role was to listen to the teachers and asked pedagogical questions regarding the teacher's enthusiasm and struggles based on experience of using the ALC.

The three teachers were all experienced, having been working for between 6-12 years. One teacher taught Swedish native language and English language, while two teachers taught software engineering and physics. The teachers were teaching on the technology programme, the electronics programme and the aesthetics programme. The class size in the observations varied between 8-18 students. Such a research setting is not without consequences. For example, the teachers' different subjects as well as the different upper secondary school programmes, both academic and vocational, have different cultures and traditions (Karaseva et al., 2013) and the fact that subjects are relays of different power and control relations (Bernstein, 2000).

The data in use here consists of 12 video recorded classroom observations of lessons in the ALC and field notes of the observations. One teacher (Joe) carried out five lessons, another teacher (Ken) carried out four lessons, and the third teacher (Aron) carried out three. The classroom observations were recorded with a Canon XA11 video camera equipped with two channels audio recordings. Thus, audio was captured through the use of two microphones, 1) one microphone on the teacher and 2) a second microphone on the camera capturing class audio. The empirical material was processed in four steps. In the first step, the first author watched and described all video recordings broadly in an excel sheet. During this step, the sequences of the classroom observation were described as a time-line in terms of: a) the activity taking place, b) the duration of the activity, c) interactions (teacher-student and student-student), d) type of setting (individual work, groupwork or mixed), e) communication quotes of teacher-student and student-student discourse. In the second step, the excel sheet describing the classroom observations was circulated around the research team and discussed. When the entire data sheet had been discussed, the research team selected typical parts that represented i) the introduction of the lesson, ii) a typical sequence when students were working, and iii) how the lesson was closed. In the third step, the selected parts were fully transcribed, both in terms of the audio and in terms of the movement, actions 
and gestures. In the fourth step, the transcriptions of the selected parts were imported to the Nvivo® software. In Nvivo ${ }^{\circledR}$, the transcriptions were organised and analysed jointly based on a theory driven approach (Stebbins, 2001) as described and illustrated in section 2.1. The analysis presented in this paper is based on the complete data sheets and the selected transcribed data.

\section{FINDINGS}

The following section presents the findings from the practice of these upper secondary school teachers in the Active Learning Classroom (ALC). The findings follow a structure that takes starting point in a photograph. The design, configuration and furnishing of a physical space, like a classroom, indicate expected power relations in that space, and the photograph is used to illustrate the expected power relations between students and teachers in the ALC. After the description of the physical ALC space (4.1) the following section (4.2) highlights the teaching practices of the teachers in the ALC with a focus on to what extent control was retained by the teacher or distributed to the students. In order to illustrate different power and control relationships, the teachers' voices are given life via frequently used quotes. The names of the teachers are replaced with pseudonyms: Joe, Aron and Ken.

\subsection{Power Relations in the Physical ALC Space}

This section reports on how the physical space of the ALC indicated power relationships between teachers and students.

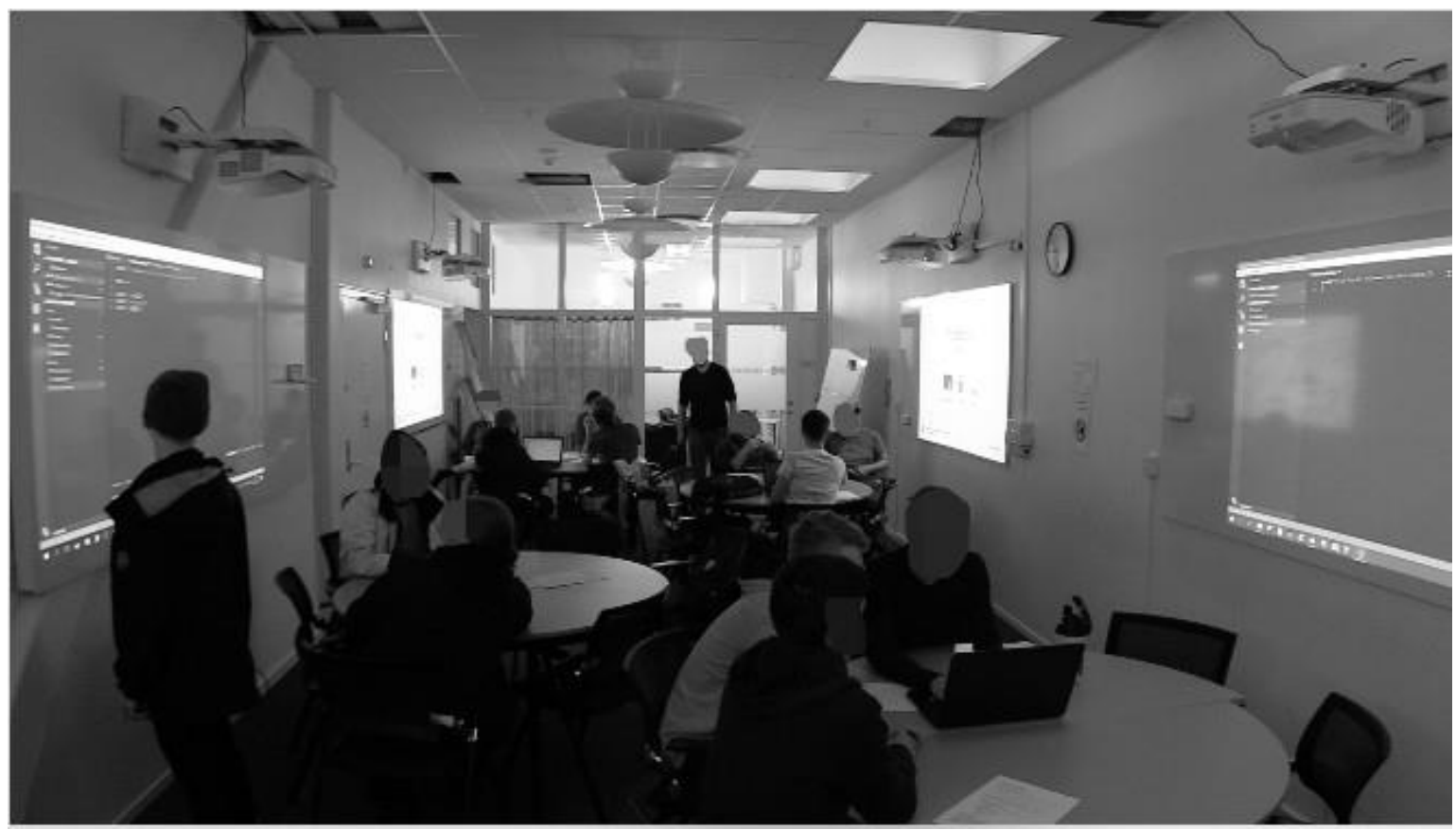

Figure 1. The physical organization of the ALC

Figure 1 illustrates how the physical space of the ALC in this study was organised in all $(\mathrm{N}=12)$ classroom observations. As illustrated in figure 2, all of the four classification categories (desks, inside-outside classroom, digital and material resources) were weakly classified: 1) desks were organised with four round tables for group student work, each desk providing space for up to 6 students, 2) no clear borders separated the ALC space from other school spaces, 3) when ICTs (e.g. the projector or smartboard) were used they were placed at student desks and used by students to show and discuss solutions among themselves and with the teacher, 4) whiteboards were placed at each student desk and used by students to show and discuss issues among 
themselves and with the teacher. In summary, all four categories indicated weak classification, thus the ALC space as such indicated a space where power was conferred to the students to a great extent.

\subsection{The Distribution of Control}

This section reports on the control of sequence and pace in the ALC over the 12 lessons. Across these 12 lessons, the analysis indicates that the teachers used a similar approach, as well as that a change was indicated in their use of control based on how they handled sequence and pace. When reporting on the findings, the analysis goes back and forth between the wider illustration of the lesson and the fully transcribed chunks of text from the selected micro sequences from the selected parts.

During the first six classroom observations the teachers typically either asked the students to continue with the task from the previous lesson (often carried through in an ordinary classroom), or gave the students a series of tasks to accomplish in groups during the observed lesson. In the words of one teacher: "When you have found the document in Google Classroom you will find the questions for discussion. You should use the same process as earlier. Discuss and be sure that everybody is allowed to talk, don't forget to take notes and then we run to 10:55 AM" (Ken, ALC \#1). When referring to process in Ken's quotation, it indicates that the teacher asked students to accomplish the task with a similar approach as they would have done in an ordinary classroom. When considering sequence and pace, the teacher asked students to dedicate about 45 minutes for group discussion. Another teacher allocated an even longer sequence of about 70 minutes: "I imagine that we will work with the task at least until the break and then we will take a look how far you have got" (Aron, ALC \#1). These two quotes indicate one long sequence before the teacher asked the students to report back. Such use of pace indicates weak framing and distribution of control from the teacher to the student: the students were given the responsibility of accomplishing the task before the time was up, and they could decide on how much time should be spent on each sequence. In the sixth classroom observation, with Aron, the approach was similar to that described above with group work and weak framing in both pace and sequence. During that lesson it was observed how the students struggled and did not make any progress, becoming more and more passive and destructive.

The seventh classroom observation, also a lesson conducted by Aron, demonstrated a stronger framing of pace and sequencing of the group work. The lesson was divided into three sequences and the teacher communicated how much time the students had for each sequence and what the students needed to accomplish in that time. At the beginning of the lesson Aron asked the students to appoint a team leader in each group and instructed them: "You are team leader, you read through the instruction and explain to the group. You have 15 minutes for the first part and to set up and start using the technology [smartboard and laptop]." This quote indicates stronger framing in both sequence and pace where it became explicit what students should do in this specific sequence and how much time they had before the sequence ended, which illustrates the teacher in control.

The next two classroom observations (\#8 and \#9), conducted by Aron and Ken, demonstrated a practice with characteristics that might be described as a mix of the above described first six and the seventh classroom observations, we noted situations of both stronger and weaker framing in sequence and pace.

During the last three classroom observations, the teachers made a joint effort to take pace and sequencing into explicit consideration when planning their lessons. They carried out one 80 minute lesson each, splitting the lessons into a greater number of sequences than they had done previously. For example, Aron and Joe split their lessons into 3-4 sequences lasting between 10-30 minutes, and Ken used a varied approach: first 4 sequences lasting 1-3 minutes, then one 30 minute sequence and thereafter a final 3 minute sequence. A typical start was to set up some rules, for example: "Aron shares the task for the first sequence, on paper, with the students and says, you are allowed to use the projectors [and one student laptop each], you are allowed to look at what other groups are doing. You have 10 minutes for the first task and after that we will have a break and see what we have" (Aron, classroom observation \#12). This quote was a typical example of how these three lessons were introduced with a clear reference to how much time the sequence should take and what comes next. Such communication indicated strong framing in both sequence and pace, which illustrates how control was retained by the teacher. Ken used a variety of sequencing during the lesson, and used a timer for keeping pace and keeping up with the sequencing plan. When working with one-minute sequences, Ken said for example: "Okay let's start, speaker number one you have one minute." This quote indicates how the teacher's focus was on controlling the activity and keeping order. In comparison to the use of one-minute sequences, Joe and Aron used 10 minutes sequences which created different conditions and frameworks for 
the students. Maybe, it was a surprise for Joe, but 4 minutes into the planned 10 minutes sequence one group said: "we've finished". Joe walked to the group, stopped and considered what they had written on the whiteboard and said: "when you have the list of categories, what can you see in each of these categories?" (Joe, classroom observation \#10). As illustrated in the quotation and in comparison to Ken's short sequences, a longer sequence can give the possibility for manoeuvring space where the teacher has the possibility of interacting with the students' process, for example when Joe asked the students to develop their answers, and then communicated this change to all four groups. Again, Joe started to move around between the groups and seemed to study what progress they were making. After another 4 minutes, he said all the groups to "Soon time will be up, one thing strikes me now when I see your list and what the list could be used for. Please, try to rank your categories in an order for what purpose you would use these things when you aim to understand a text" (Joe, classroom observation \#10). This quote indicates another intervention into students process by asking them gently to make a last effort before whole class discussion. After another 2 minutes Joe breaks and finalises the sequences. The quotes from Joe's communication indicate the use of strong framing of sequence and pace, where it was the teacher who controlled the order in which things should be done, as well as how fast a task should be accomplished.

\section{DISCUSSION}

The aim of this study was to explore teaching in an active learning classroom (ALC) from the perspective of power and control, highlighting the organisation of the physical learning environment of the ALC and teacher practices within the ALC, and discussing what type of practices enhanced active learning. Considering the physical space of the ALC, the analysis of the four classification categories (desks, inside-outside the classroom, digital and material resources) indicated weak classification. The classroom design with round tables and student access to both digital and physical resources provided an environment suited to student-centred group work. Along with Bernstein (2000), we argue that the organisation of the physical space indicated a shift in power from teacher to student, and distribution of symbolic power to students.

Considering the teacher practices, the findings indicated that the design of the ALC supported student-centred activities and student discussion and analysis (cf. Bonwell \& Eison, 1991). However, as students were more in control of the classroom activities, the outcome from teaching and learning was not obvious and the teachers became frustrated. The analysis further indicated that when control was taken back by teachers in terms of more strict control over pace and sequencing, the students' productivity increased, something that other studies have also found (Bernard et al, 2019). Our understanding is that that the physical space built for student-centred group work (RQ1) "forced" the teachers in practice to work with pace and sequencing to handle control (RQ2), and that this in turn actually led to increased productivity and more active learning among the students - the students worked more intensively in groups with the tasks when the teacher had more active pace and sequencing control (RQ3).

\section{CONCLUSION}

In general, this study aimed to contribute an understanding of teaching in a context of the Active Learning Classroom (ALC) that put pressure on teachers to use this new learning environment, to use ICTs and to apply new pedagogies. This study is one of the first where teachers in upper secondary school recontextualised the ALC as both space and practice. This was accomplished, first, by entering a physical classroom space designed for group work and which signalled a shift in power from teacher to student, and secondly, through a shift in teaching practice that involved teachers' work on control over sequence and pace. The findings from this study can be used to help teachers design active learning by using the categories as design elements in planning.

This study contains some methodological limitations based on the research project's characteristic of being both a research and a development project. This made us as researchers be involved to some extent in the teachers' process. Another limitation concerns the unequal amount of classroom observation between the teachers, based on their personal feel, and comfort, of throwing themselves into the ALC. Another limitation concerns the wide spread between academic and vocational programmes at the outset, and towards the last classroom observations only focusing on one programme. A stronger focus on, for example, solely the technology programme might possibly provide other types of findings. 


\section{REFERENCES}

Baepler, P., Walker, J.D., \& Driessen, M. (2014). It's not about seat time: Blending, flipping, and efficiency in active learning classrooms. Computers \& Education. 78. 227-236. Doi:10.1016/j.compedu.2014.06.006

Baepler, P., Walker, J.D., Brooks, C.D., Saichaie, K., and Petersen, C.I. (2016). A guide to teaching in the active learning classroom: history, research and practice. Stylus Publishing: Sterling.

Barr, R. B., \& Tagg, J. (1995). From Teaching to Learning - A New Paradigm for Undergraduate Education. Change, November/December.

Beck, K. and Ralph, J., 1994. Patterns Generates Architectures. Proceedings of European Conference of Object-Oriented Programming. Bologna, Italy, pp. 139-149.

Bergström, P. (2019). Illustrating an analysing power and control relations in Finnish one-to-one computing clasrooms: Teacher practices in grade 7-9. Nordic Journal of Digital Literacy, In Press.

Bergström, P., \& Mårell-Olsson, E. (2018). Power and control in the one-to-one computing classroom: students' perspective on teachers' didactical design. Seminar.net: media, technology and lifelong learning, 14(2), 160-173.

Bergström, P., Mårell-Olsson, E., \& Jahnke, I. (2019). Variations of symbolic power and control in the one-to-one computing classroom: Swedish teachers' enacted didactical design decisions. Scandinavian Journal of Educational Research. 63(1). 38-52. doi:10.1080/00313831.2017.1324902

Bernard, R.M., Borokhovski, E., Schmid, R.F., Waddington, D.I., and Pickup, D.I. (2019). Twenty-first century adaptive teaching and individualized learning operationalized as specific blends of student-centred instructional events: A systematic review and meta-analysis. Campbell Systematic Reviews. 2019;15:e1017. 1-35. Doi: 10.1002/cl2.1017.

Bernstein, B. (2000). Pedagogy, Symbolic Control and Identity: Theory, Research, Critique (Revised Edition ed.). Lanham: Rowman \& Littlefield Publishers, Inc.

Bonwell. C.C., \& Eison, J.A. (1991). Active learning: Creating excitement in the classroom. ASHE-ERIC Higher Education Report No 1. Washington, DC: George Washington University. Retrieved from https://files.eric.ed.gov/fulltext/ED336049.pdf.

Brooks, C.D. (2011) Space matters: The impact of formal learning environments on student learning. British journal of educational technology. 42(5), 719-726

Carlgren, I., Klette, K., Mýrdal, S., Schnack, K., \& Simola, H. (2006). Changes in Nordic Teaching Practices: From individualised teaching to the teaching of individuals. Scandinavian Journal of Educational Research, 50(3), 301-326. doi:10.1080/00313830600743357

Friere, P. (1970). Pedagogy of the opressed. New York: Continuum.

Hattie, J. (2008). Visible learning: A synthesis of over 800 meta-analyses relating to achievement. London and New York: Routledge.

Hyun, J., Ediger, R., \& Lee,D. (2017). Students' Satisfaction on Their Learning Process in Active Learning and Traditional Classrooms. International Journal of Teaching and Learning in Higher Education. 29(1). 108-118.

Jahnke, I., Bergström, P., Mårell-Olsson, E., Häll., L, \& Kumar, S. (2017). Digital didactical design as research framework: iPad integration in Nordic schools. Computers and Education. 113. 1-15. Doi: 10.10.16/j.compedu.2017.05.006

Karaseva, A., Pruulmann-Vengerfeldt, P., \& Siibak, A. (2013). Comparison of different subject cultures and pedagogical use of ICTs in Estonian schools. Nordic Journal of Digital Literacy, 8(3), 157-170.

King, A. (1993). Sage on the stage to guide on the side. College Teaching, 41(1), 30-35.

Lundahl L., Gruffman Cruse, E., Malmros, B., Sundbaum, A-K.,\& Tieve, Å. (2017). Pedagogisk rum-tid och strategier för aktivt lärande I högre utbildning. Utbildning \& lärande, 11(1), 16-32.

OECD (2013). Innovative Learning Environments. Educational Research and Innovation. Paris: OECD. Retrieved from http://dx.doi.org/10.1787/9789264203488-en

Stebbins, R. A. (2001). Exploratory research in the social sciences (Vol. 48 ). London: Sage Publications, Incorporated.

Whiteside, A., Brooks, C. D., and Walker, J.D., (2010). Making the Case for Space: Three Years of Empirical Research on Learning Environments. Educause Quarterly, 33. 